\title{
PENYELESAIAN SENGKETA PERTANAHAN MELALUI LEMBAGA ARBITRASE
}

\author{
Hasnan Hasbi \\ Dosen Tetap Fakultas Hukum Universitas Muslim Indonesia Makassar \\ email : Hasbi hasnan@yahoo.com
}

\section{Abstract}

The arbitral tribunal may be applied to the object of civil disputes of land, whether lands that have land rights or land that have no rights. Mechanisms and procedures of land arbitration agencies are very simple as arbitration courts in trade disputes and banking only need to be added a phase of data analysis and consideration to find a synchronization between data and information, between juridical data and physical data, in order to get a fair and right decision.

Keywords: Land Dispute; Arbitration Institution;

\section{Abstrak}

Pengadilan arbitrase dapat diterapkan pada objek sengketa perdata tanah, apakah tanah yang memiliki hak atas tanah atau tanah yang tidak memiliki hak. Mekanisme dan prosedur agen arbitrase tanah sangat sederhana karena pengadilan arbitrase dalam sengketa perdagangan dan perbankan hanya perlu menambahkan fase analisis data dan pertimbangan untuk menemukan sinkronisasi antara data dan informasi, antara data yuridis dan data fisik, untuk mendapatkan keputusan yang adil dan benar.

Kata kunci: Sengketa Tanah; Arbitrase;

\section{A. PENGANTAR}

Peningkatan kebutuhan manusia seperti ruang dan tanah tersebut, menyebabkan nilai dan harga tanah semakin terbatas atau semakin sempit. Fenomena seperti ini menyebakan konflik dan sengketa tanah semakin banyak, baik dalam hal penguasaannya maupun dalam hal pemanfaatannya.

Untuk menyelesaikan sengketa dan kasus-kasus yang berkaitan dengan tanah, pada umumnya dilakukan melalui lembaga peradilan formal yang telah ada, baik dalam kasus-kasus pidana, sengketa perdata maupun sengketa tata usaha negara. Secara umum lembaga peradilan telah berusaha menyelesaikan banyak sengketa pertanahan yang diajukan kepada lembaga tersebut, namun terkadang lembaga itu tidak mampu untuk melakukan penyelesaian sengketa yang terjadi secara tuntas termasuk dalam memberikan rasa keadilan kepada semua pihak yang terkait.

Hal-hal yang selalu menjadi masalah adalah seringnya terjadi penyimpangan dalam penerapan hukum, seperti salah eksekusi atas obyek sengketa karena adanya kekeliruan dalam pengajuan obyek sengketa. Dan bahkan putusan hakim tersebut sudah bersifat final, namun pada kenyatannya 
tidak dapat dilakukan eksekusi, sebagai akibat amar putusan yang disebutkan tidak jelas perintahnya ataupun karena pihak-pihak yang telah dinyatakan kalah oleh pengadilan ternyata tidak bersedia memenuhi amar putusasn yang telah mempunyai kekuatan hukum tetap.

Peramasalahan-permasalah tersebut terjadi karena sengketa-sengketa mengenai pertanahan tidak sekedar menyangkut sengketa materil semata, tetapi kadang-kadang bersifat non materil bahkan dapat menjadi kasus atau sengketa yang bermuatan politis. Adapun hal-hal tersebut terjadi karena dipengaruhi oleh beberapa faktor antara lain :

1. Sikap yang muncul dari dalam diri para pihak seperti menyangkut kehormatan dan harga diri antara pihak-pihak yang bersengketa sehingga ada kesan bahwa sejengkal tanahpun akan tetap dipertahankan meskipun mereka harus mengeluarkan biaya perkara yang jauh lebih besar dari nilai tanah itu sendiri.

2. Lembaga pengadilan yang dikelilingi oleh mafia peradilan serta adanya indikasi advokat yang tidak dapat menjamin obyektivitas dalam beracara.

3. Tidak independennya pengadilan karena adanya intervensi dari pihak eksekutif dalam kasus-kasus tertentu misalnya kasus yang bernuansa politik dan sebagainya (Karimsyah).

Pelaksanaan sistem peradilan di Indonesia dan gagalnya komunitas hukum untuk melakukan penyelesaian sengketa yang begitu lama adalah salah satu penyebab begitu banyaknya penumpukan perkara (congestion) di dalam sistem peradilan perdata. Di dalam pengadilan, pengembangan mekanisme penyelesian sengketa secara komperatif memiliki potensi layak dikembangkan serta didayagunakan.

Fenomena-fenomena tersebut dapat menimbulkan rasa keraguan bagi masyarakat pencari keadilan yang berakibat pada menurunnya kepercayaan masyarakat terhadap lembaga peradilan formal sehingga timbul pemikiran untuk mencari alternatif lain dalam upaya penyelesaian sengketa tanpa melalui pengadilan yang dikenal dengan istilah Alternative Dispute Resolution (ADR) dimana didalamnya terdapat beberapa pilihan metode penyelesaian sengketa diluar peradilan seperti mediasi, konsiliasi, negosiasi dan arbitrase.

Masing-masing metode tersebut memiliki kekurangan dan kelebihan sehingga alternatif yang dipilih dapat disesuaikan dengan kebutuhan dan kepentingan para pihak yang bersengketa. Salah satu metode alternatif penyelesaian sengketa yang menarik untuk dibahas sebagai solusi dalam menyelesaikan sengketa pertanahan yaitu melalui arbitrase (Maria SW Sumardjono).

Sebagaimana diketahui bahwa arbitrase merupakan salah satu alternatif dalam penyelesaian sengketa yang umumnya dipergunakan dalam sengketasengketa bisnis dan perdagangan, namun penulis mencoba mendekatkan konsep ini dalam upaya menyelesaikan sengketa-sengketa pertanahan. Menurut Maria SW Sumardjono (193 : 2007) gagasan membentuk lembaga arbitrase pertanahan masih memerlukan pemikiran yang seksama. Apabila semua unsur 
yang dipertimbangkan untuk terciptanya lembaga arbitrase itu sudah dapat dipenuhi, mungkin gagasan itu dapat terwujud. Gagasan tentang arbitrase pertanahan muncul sebagai reaksi atas penyelesaian sengketa melalui pengadilan yang berjalan lamban dan terkadang tidak dapat dieksekusi.

\section{B. ANALISIS DAN PEMBAHASAN}

\section{Gambaran Umum Arbitrase}

\section{a. Konsep Arbitrase Dalam Hukum Positif}

Sejak disahkannya Undang-Undang Nomor 30 Tahun 1999 tentang Arbitrase dan Altematif Penyelesaian Sengketa. maka sejak saat itu pula pemikiran tentang arbitrase semakin berkembang, kekuasaan kehakiman dapat dilakukan melalui badan-badan peradilan yang telah diatur dengan undang-undang namun dapat pula ditempuh penyelesaian suatu sengketa melalui perdamaian.

Dalam Pasal 10 Undang-Undang Nomor 48 Tahun 1999 Tentang Kekuasaan Kehakiman ditetapkan sebagai berikut:

a) Pengadilan dilarang menolak untuk memeriksa, mengadili dan memutus suatu perkara yang diajukan dengan dalih bahwa hukum tidak ada atau kurang jelas, melainkan wajib untuk memeriksa dan mengadilinya.

b) Ketentuan dalam ayat (1) tidak menutup kemungkinan untuk usaha penyelesaian perkara perdata secara perdamaian.

Kententuan yang di atur dalam pasal di atas selanjutnya dijelaskan dalam penjelasan Undang-Undang Nomor 48 Tahun 2009 pasal 2 ayat (3) yang menyebutkan bahwa pasal ini mengandung arti bahwa selain peradilan negara, tidak diperkenankan lagi adanya peradilan-peradilan yang dilakukan bukan oleh peradilan negara. Penyelesaian perkara diluar pengadilan atas dasar perdamaian atau melalui wasit (arbitrase) tetap diperbolekan

Karena penyelesaian sengketa atau perkara lewat arbiter tidak dianggap sebagai suatu peradilan melainkan hanya sebagai salah satu dari upaya perdamaian diluar pengadilan artinya bahwa sebelum suatu perkara atau sengketa perdata diselesaikan melalui peradilan umum maka selalu terbuka kesempatan untuk menyelesaikan perkara atau sengketa perdata tersebut diluar peradilan sehingga penyelesaian sengketa perdata melalui acara peradilan umum merupakan pilihan terakhir bagi pihak-pihak yang bersengketa. Pada setiap acara persidangan atas perkara perdata, pada sidang pertama Hakim selalu menawarkan kepada para pihak untuk menempuh upaya perdamaian.

Arbitrase yang merupakan salah satu aternatif penyelesaian sengketa (alternative disputes resolution) yang bertujuan untuk menyelesaikan perkara atau sengketa perdata diluar pengadilan yang 
tetap memberikan jaminan kepastian hukum dengan menggunakan metode beracara yang mirip dengan acara pada peradilan formal.

Namun demikian peradilan arbitrase ini bukanlah suatu lembaga peradilan sebagaimana yang dimaksudkan oleh UndangUndang Nomor 48 Tahun 2009 Pasal 2 ayat (3) yang menyatakan bahwa "Semua Peradilan di seluruh wilayah Negara Republik Indonesia adalah Peradilan Negara yang diatur dengan Undang Undang".

Menurut Yahya Harahap (2001:83), arbitrase bukan badan kekuasaan peradilan (judicial power) resmi yang sengaja didirikan oleh kekuasaan negara berdasarkan konstitusi ketatanegaraan dari negara yang bersangkutan. Atas kenyataan bahwa arbitrase bukan badan peradilan resmi, menyebabkan sebutan populernya lazim dikatakan "juru pisah persengketaan" seolah-olah dalam menjalankan fungsi dan kewenangan memutus sengketa bukan mengadili tetapi lebih menyelesaikan perselisihan.

Dalam perkembangan selanjutnya, kehadiran Undang-Undang Nomor 30 Tahun 1999 tentang Arbitrase dan Alternatif. Penyelesaian sengketa, dalam konsiderannya memberikan pertimbangan sebagai berikut :

a. Bahwa berdasarkan peraturan perundang-undangan yang berlaku, penyelesaian sengketa perdata disamping dapat diajukan ke peradilan umum juga terbuka kemungkinan diajukan melalui arbitrase dan alternatif penyelesaian sengketa.

b. Bahwa peraturan perundang-undangan yang kini berlaku untuk penyelesaian sengketa melalui arbitrase sudah tidak sesuai lagi dengan perkembangan dunia usaha dan hukum pada umumnya.

Dalam kenyataannya tidak semua perkara atau sengketa perdata dapat diselesaikan melaui arbitrase melainkan hanya perkara atau sengketa perdata yang dimungkinkan untuk dilakukan perdamaian sebagaimana dijelaskan dalam pasal 5 ayat (2) Undang-undang Nomor 30 Tahun 1999 tentang Arbitrase dan Alternatif Penyelesaian Sengketa.

Pasal 1 ayat (1) Undang-Undang Nomor 30 Tahun 1999 tentang Arbitrase dan Altematif Penyelesaian Sengketa memberikan pengertian bahwa arbitrase adalah cara penyelesaian satu sengketa perdata di luar peradilan umum yang berdasarkan pada perjanjian arbitrase yang dibuat secara tertulis oleh para pihak yang bersengketa. Artinya bahwa sengketa perdata yang dapat diselesaikan melalui arbitrase menurut ketentuan ini adalah sergketa yang berasal dan perjanjian yang telah diikat oleh suatu kesepakatan untuk menundukkan diri pada lembaga arbitrase balk kesepakatan itu dilakukan sebelum terjadinya sengketa maupun kesepakatan yang dilakukan setelah terjadinya sengketa. 


\section{b. Perjanjian Arbitrase}

Perjanjian arbitrase (factum arbiriil) adalah perjanjian tertulis yang bersifat assesor, bukan perjanjian bersyarat atau voorwaardelijke verbentenis sebagaimana dimaksud dalam pasal 1253-1267 KUH Perdata.Oleh karena itu pelaksanaan perjanjian arbitrase tidak digantungkan kepada sesuatu yang akan terjadi dimasa yang akan datang.

Ada pendapat yang mengajarkan bahwa klausula arbitrase bukan public order atau niet van openbaar orde artinya klausula arbitrase tidak mutlak menyingkirkan kewenangan pengadilan negeri untuk memeriksa dan mengadili perkara yang timbul dan perjanjian (Yahya Harahap, 2001:84), seumpama salah satu pihak mengajukan sengketa mereka ke pengadilan negeri sedangkan pihak lawannya tidak mengajukan eksepsi atau bantahan bahwa perjanjian mereka telah diikat dengan klausula arbitrase maka lahir anggapan bahwa mereka telah sepakat untuk ingkar terhadap klausula arbitrase sehingga penarikan din itu tidak dapat dikatakan sebagai penankan secara diam-diam.

Pacta Sunt Servanda mengandung makna setiap pejanjian yang sah (Legal agreement) mengikat kepada para pihak atau agreement or promisemust be keps, oleh karena itu para pihak harus menaatinya (Yahya Harahap, 2001.88).

Makna dan Asa Pacta Sunt Servanda itu telah dituangkan dalam Pasal 1338 KUH Perdata yang berbunyi " Semua persetujuan yang dibuat sesuai dengan undang-undang berlaku sebagai undang-undang bagi mereka yang membuatnya Persetujuan itu tidak dapat ditarik kembali selain dengan kesepakatan kedua belah pihak, atau karena alasan-alasan yang ditentukan oleh undang-undang, persetujuan harus dilaksanakan dengan itikad baik".

Perjanjian arbitrase tidak mempersoalkan hal pelaksanaan perjanjiannya tetapi hanya mempersoalkan masalah cara dan lembaga yang berwenang menyelesaikan perselisihan yang terjadi antara pihak yang berjanji. Adapun fokus dari perjanjian arbitrase 'klausula arbitrase" sematamata menyangkut penyelesaian perselisihan yang timbul dari perjanjian.Jadi perjanjian arbitrase tidak melekat menjadi satu kesatuan dengan materi pokok perjanjian tetapi merupakan tambahan yang dilekatkan kepada perjanjian pokok, itu sebabnya disebut perjanjian yang bersifat assesoris.

Penggunaan istilah klausula arbitrase dalam perjanjian pokok artinya bahwa perjanjian pokok yang dimaksud diikuti atau dilengkapi. dengan perikatan arbitrae. Berdasarkan berbagai sumber undang-undang, peraturan maupun konvensi intemasional dapat dijumpai dua bentuk persetujuan arbitrase atau klausula arbitrase yaitu Pactum De Compromittendo (Kesepakatan) and Settlement (Perdamaian yang dicapai di luar pengadilan) biasa juga disebut akta Kompromis. 
Bentuk klausula arbitrase " Pactum De Compromittendo" ini menurut Pasal 615 ayat (3) Rv dan Pasal II Konvensi New York 1958 berbunyi "adalah diperkenalkan mengikatkan diri satu sama lain untuk menyerahkan sengketa-sengketa yang mungkin timbul di kemudian har kepada putusan seorang atau beberapa orang arbiter atau wasit "(Yahya Harahap 2001:65).

Pasal 11 ayat (2) undang-undang tahun 301999 tentang arbitrase dan Alternatif penyelesaian sengketa menyebutkan secara tegas bahwa "pengadilan negeri wajib menolak dan tidak akan campur tangan di dalam penyelesaian sengketa yang telah di teteapkan melalui arbitrase kecuali dalam hal-hal tertentu yang di tetapkan dalam undang-undang ini." Pactum De Compromittendo adalah klausa arbitrase yang bersifat mengikat sehingga penyelesaiannya wajib dilakukan oleh arbiter atau majelis arbitrase oleh karena itu pengadilan harus menolak untuk mengadilinya.

Lain halnya dengan Akta kompromis atau perjanjian kesepakatan yang di buat oleh para pihak setelah terjadinnya sengketa perdata artinya mereka memilih alternatif untuk menyelesaikan sengketa diantara melalui arbittrase sehingga perkaranya tidak perlu dibawa kehadapan sidang pengadilan umum dan mereka menundukkan diri terhadap keputusan majelis arbitrase yang mereka setujui bersama.

\section{Arbitrase Dalam Menyelesaikan Sengketa}

Satu setengah abad yang lalu seorang presiden Amerika serikat pernah melontarkan gagasan dalam penyelesaian sengketa melalui media nonlitigasi, Abraham Lincoln pada tahun 1850 membuat berapa catatan tentang apa yang dipikirkan oleh para sejarawan, ia menulis catatan yang ditujukan untuk kelompok sesamanya pengacara adapun sebahagian dari apa yang di tulis Lincoln adalah :

"Perkecillah peran pengadilan bujuklah para tetangga anda untuk berkompromi sepanjang yang anda dapat lakukan tunjukkan pada mereka bagaimana orang yang hanya namanya saja disebut sebagai pemenang ,tetapi serung di dalam kenyataannya lebih merupakan pihak nyata-nyata kalah yaitu dalam biaya pembayaran dan pemborosan waktu." (Achmad Ali 2003 : 1)."

Catalan kecil di atas merupakan gambaran yang nyata dalam praktek peradilan dimana-mana, bila disimak dari inti kalimatnya maka sesungguhnya Abraham Lincoln mengajak kita untuk bersama-sama menyelesaikan sengketa yang dihadapi tanpa harus melibatkan pihak pengadilan yaitu dengan memilih cara penyelesaian non-litigasi termasuk didalamnya adalah arbitrase.

\section{a. Memilih Arbitrase sebagai upaya penyelesaian sengketa}

Konsep budaya hukum kita yang komunalistik-religius dan bersendikan adat telah terbangun sejak lama kemudian menyusul pemerintahan kolonial belanda yang menguasai indonesia lebih dari tiga 
setengah abad sangat mewarnai perkembangan hukum kita yang bergeser kearah positivisme hukum. Faham komunalistik-religius yang telah tertanam sekian lama telah bergeser secara perlahan mengikuti perkembangan masyarakat hukum legalitas-formal yang serba tertulis dimana semua ketentuan hukum tercatat dalam suatu kitab hukum yang terkodifikasi.

Fenomena kehidupan hukum seperti itu masih tampak hingga sekarang ini dimana masyarakat lebih yakin dan lebih cenderung untuk menyelesaikan setiap sengketa atau masalah yang mereka hadapi melalui jalur litigasi yang serba kaku dalam pelaksanaannya. Apalagi dengan campur tangan pihak ketiga yaitu pengacara dimana mereka hanya cenderung untuk mencapai suatu kemenangan bagi kliennya semata dan bukan untuk mengungkapkan suatu kebenaran.

Kecenderungan diatas mendominasi kenyataan hukum dalam kehidupan sehari-hari dimana oleh kebanyakan masyarakat tidak mengetahui bahwa sebenarnya ada altematif lain yang dapt ditempuh dalam menyelesaikan masalah atau sengketa yang timbul. Namun karena sosialisasi yang tidak maksimal dalam memperkenalkan isi, maksud dan tujuan diadakannya Undang-Undang Nomor 30 Tahun 1999 tentang Arbitrase dan Alternatif penyelesaian Sengketa yang tidak langsung menyentuh kalangan masyarakat umum. Hal itu terbukti dengan tidak adanya reaksi dari masyarakat setelah empat tahun undang-undang ini berlaku namun gaungnya dalam masyarakat tidak pernah muncul.

Sampai saat ini belum pernah terdengar atau diberitakan baik melalui koran maupun media elektronik tentang sesuatu sengketa atau kasus yang diselesaikan lewat media arbitrase. Dalam literatur-literatur terdapat beberapa contoh kasus yang diselesaikan melalui lembaga arbitrase namun sosialisasinya masih sangat terbatas pada kalangan akademik terbatas saja yaitu kalangan pemerhati perkembangan hukum perdata. Jika memahami hakekat maupun kelebihan yang dimiliki arbitrase maka seharunya pihakpihak yang bersengketa lebih cenderung memilih cara ini dalam menyelesaikan sengketanya daripada mereka menempuh cara litigasi, namun kenyataannya dalam masyarakat masih jauh dan apa yang diharapkan oleh undang-undang arbitrase ini.

\section{b. Sosialisasi Arbitrase}

Undang-Undang Nomor 30 Tahun 1999 tentang Arbitrase dan Altematif Penyelesaian Sengketa ini diundangkan pada tanggal 12 Agustus 1999 melalui Lembaga Negara Republik Indonesia Tahun 1999 Nomor 138. Ketika itu suasana reformasi dan keterpurukan ekonomi menyita perhatian semua kalangan sehingga gaung arbitrase ini tidak terdengar sama sekali.

"Pemberitaan tentang lahirnya undang-undang ini seperti sepi saja. la kalah pamornya dengan berita-berita politik atau ekonomi. Sesungguhnya undang-undang ini perlu hangat. la periu disebarluaskan (disosialisasikan) biar masyarakat luas tertuma pengusaha dan mahasiswa tahu apa itu arbitase, mengapa ada arbitase, dan apa 
isi undang-undang arbitase yang baru". (Huala Adolf, dalam Proposek dan Pelaksanaan Arbitase di Indonesia. Priyatna Abdurrasyid dkk, 2001:76).

Seandainya sosialisasi dan pengenalan arbitrase ini masyarakat berlangsung sebagaimana sosialisasi ketentuan hukum publik lainnya seperti halnya sosialisasi undang-undang tentang psykotropika dan undang-undang tentang lalulintas dan jalan raya maka fenomena peradilan dan penyelesaian sengketa dalam masyarakat akan lain dan tidak seperti sekarang ini yang mana kecenderungan untuk terus meningkat jumlah kasus atau sengketa yang tertunggak di Mahkama Agung.

Selain kalangan penulis dan kaum akademis maka ada beberapa pihak yang sangat efektif dalam memperkenalkan arbitrase ini kepada mesyarakat yaitu polisi sebagai penyidik, pengacara atau penasehat hukum, hakim, wartawan atau media pers.

Polisi dalam fungsinya sebagai penyidik merupakan komponen hukum yang efektif untuk memperkenalakan konsep arbitase kepada masyarakat khususnya kepada mereka yang sedang bersengketa. Hal itu dapat saja terlaksana jika yang bersangkutan telah memahami dan mengetahui perihal arbitase dengan segala manfaat dan kelebihannya sehingga mereka dapat memperkenalkan substansi yang termuat dalam Undang-Undang Nomor 30 tahun 1999 dengan menawarkan suatu proses penyelesaian sengketa dengan arbitase yang diawali dengan suatu akta kompromis.

Pengacara ataupun penasehat hukum termasuk komponen hukum di dalam masyarakat, idealnya mereka lebih banyak mengetahui perihal arbitase sehingga merekalah yang paling berpotensi melakukan sosialisasi arbitase kepada masyarkat. Sedangkan Hakim dalam peranannya melakukan sosialisasi arbitase sangat terbatas karena kesempatan itu hanya terjadi ketika sidang pengadilan sedang berlangsung.

\section{c. Lembaga-Lembaga Arbitrase di Indonesia}

Di negara-negara lain baik di Eropa dan Amerika maupun di Asia seperti di Jepang. Singapura bahkan di Malasyia sudah ada lembagalembaga arbitrase yang berkembang dan telah berjasa menyelesaikan sengketa-sengketa perdata dengan hasil yang memuaskan para pihak karena independensi, profesionalisme dan krebilitasnya yang tetap terjaga.

Keberadaan lembaga-lembaga arbitrase di Indonesia belum banyak dikenal oleh masyarakat pencari keadilan, hal ini lebih banyak disebabkan karena kurangnya sosialisasi oleh pihak pihak yang berkompetensi.

Lembaga arbitrase yang pertama di Indonesia terbentuk sejak tahun 1977 atas prakarsa Kamar Dagang dan Industri Indonesia (Kadin) maka didirikanlah Badan Arbitrase Nasional Indonesia (BANI) di Jakarta pada tanggal 03 Desember 1977 dengan tujuan untuk memberikan penyelesaian yang adil dan cepat dalam sengketa-sengketa perdata yang timbul mengenai soal-soal yang berhubungan dengan perdagangan. industri dan 
keuangan baik yang bersifat nasional maupun bersifat internasional (A.Rahmat Rosyida dan Ngatino,2002:93).

Badan Arbitrase Muamalat Indonesia disingkat BAMUI adalah yayasan yang dibentuk berdasarkan Akta Notaris tanggal 21 Oktober 1993 Nomor 175 di Jakarta atas gagasan dari majelis ulama Indonesia, BAMUI sebagai lembaga permanen yang berfungsi untuk menyelesaikan kemungkinan terjadinya sengketa perdata diantara bank Islam dengan nasabah-debiturnya. (A.Rahmat Rosyida dan Ngatino, 2002 103).

Konsep yang diajukan oleh Maria S. W. Sumadjono tentang gagasan pembentukan arbitrase pertanahan dimasa yang akan datang bukanlah suatu hal yang tidak mungkin terwujud karena pertimbangan kebutuhan masyarakat ke depan dimana dibutuhkan suatu pelayanan hukum yang benar-benar dapat memberikan rasa keadilan, membenkan kemanfaatan serta kepastian hukum.

\section{Arbitrase Menurut Undang-Undang Nomor 30 Tahun 1999}

Pelaksanaan arbitrase di Indonesia menurut Udang-Undang Nomor 30 tahun 1999 tentana Arbitrase dan Altematif Penyelesaian Sengketa, beritik tolak dari pasal 2 yang berbunyi bahwa : "Undang-Undang ini mengatur penyelesaian sengketa atau beda pendapat antar para pihak dalam suatu hubungan hukum tertentu yang telah mengadakan perjanjian arbitrase yang secara tegas menyatakan bahwa semua sengketa atau beda pendapat yang timbul atau mungkin timbul dari hubungan hukum tersebut akan diselesaikan dengan Cara arbitrase atau melalui altematif penyelesaian sengketa".

Kemudian dalam Pasal 6 ayat (9) menyebutkan bahwa "apabila usaha perdamaian sebagaimana dimaksud dalam ayat (1) sampai dengan ayat (6) tidak dapat dicapai, maka para pihak berdasarkan kesepakatan secara tertulis dapat mengajukan usaha penyelesaiannya melalui lembaga arbitrase atau arbitrase ad-hoc."

Arbitrase ad-hoc atau arbiter volunter adalah arbitrase yang tertentu sehingga arbitrase ini bersifat insidental dan jangka waktu tertentu. Dalam pelaksanaanya arbitrase ad-hoc ini memiliki kesulitankesulitan melakukan negosiasi dan menetapkan aturan-aturan prosedural dari arbitrase serta kesulitan dalam merencanakan metode metode pemilihan arbitrase yang dapat ditenma oleh kedua bela pihak. (Gunawan Wijaya dan ahmad Yani, $2001: 53)$.

Adapun fase penyelenggara Arbitrase menurut ketentuan UndangUndang Nomor 30 tahun 1999 tentang Arbitrase dan Alternatif Penyelesaian Sengketa terbagi menjadi tiga fase yaitu fase pertama pengangkatan dan penetapan arbiter, fase kedua adalah acara arbitrase dan fase ketiga adalah pengambilan putusan dan pelaksanaan putusan arbitrase. 
Ketiga fase tersebut di atas dapat diuraikan sebagai berikut :

\section{a. Penepatan Arbiter}

Penyelenggara arbitrase berawal dari penunjukkan arbiter atau majelis arbiter yang telah ditetapkan oleh para pihak dalam klausula arbitrase, jika dalam klausula tidak disebutkan secara tegas maka penetapan arbitrase dilakukan oleh Ketua Pengadilan Negeri atas usul dari para pihak.

Terhadap arbitrase ad-hoc, maka pengangkatannya ditetapkan oleh Ketua Pengadilan Negeri atas usul dan para pihak pula seandainya yang diusulkan adalah arbiter tunggal sebagai mana yang disebutkan dalam pasal 14 Undang-Undang Nomor 30 Tahun 1999.

Seorang atau beberapa orang arbiter dapat mengajukan penolakan bilamana muncul keraguan dalam dirinya bahwa is tidak dapat mempertahankan obyektivitas dalam menjalankan fungsinya sebagai arbiter. Hak menolak dari arbiter ini tercatat dalam pasal 16 ketentuan arbitrase di atas, bahkan pengunduran diri dari posisi arbiter masih dimungkinkan oleh pasal 19 ketentuan arbiter.

Hak ingkar ialah hak pihak yang bersengketa untuk menolak arbiter yang telah diangkat oleh Ketua Pengadilan Negeri, hak ini dapat diajukan apabila terdapat cukup bukti yang otentik yang menimbulkan keraguan bahwa arbiter yang diangkat tidak dengan penetapan pengadilan maka hak ingkar itu diajukan langsung kepadanya.

\section{b. Tahap Pemeriksaan}

Setelah ditetapkan arbiternya, maka selanjutnya dilakukan pemeriksaan sengketanya. Pemeriksaan ini dilakukan secara tertutup untuk menjaga privasi dari para pihak dan pemeriksaan dilakukan dengan menggunakan bahasa indonesia kecuali ada kesepakatan lain.

Dalam pemeriksaan oleh arbiter atau majelis arbiter para pihak mempunyai hak yang sama untuk mengemukakan pendapatnya termasuk hak untuk mengajukan permohonan kepada arbiter untuk mengambil putusan sela dan penetapan sita jaminan. memerintahkan penitipan barang kepada pihak ketiga atau menjual barang yang mudah rusak.

Dalam pemeriksaan sengketanya para pihak bebas untuk menentukan acara arbitrase yang digunakan sepanjang tidak bertentangan dengan ketentuan Undang-Undang ini misalnya dalam pemeriksaan sengketanya harus dilakukan secara tertulis namun dapat juga dilakukan secara lisan jika hal itu disetujui oleh para pihak yang bersengketa. Tempat penyelenggara arbitrase ditentukan oleh arbitrase atau majelis arbitrase kecuali ditentukan sendiri oleh para pihak.

Pemeriksaan saksi dan saksi ahli jika diperlukan akan dilakukan sesuai ketentuan hukum acara perdata. Keterangan saksi tersebut dapat dilakukan di tempat tertentu dimana saja. Semua kegiatan dalam pemeriksaan dan sidang arbitrase dicatat dalam Berita Acara Pemeriksaan 
bilamana ada hal yang kurang jelas oleh para pihak maka arbiter atau majelis arbitrase atas permintaan para pihak dapat memanggil saksi atau saksi ahli untuk didengar penjelasannya dihadapan sidang arbitrase yang dihadiri oleh para pihak.

\section{c. Putusan Arbitrase}

Apabila pemeriksaan sengketa telah selesai, maka tahap pemeriksaan ditutup dan ditetapkan hari sidang untuk mengucapkan putusan arbitarase. Arbitrase atau majelis arbitrase dalam mengambil keputusan dan sengketa tersebut berdasarkan ketentuan hukum atau berdasarkan keadilan dan kepatuhan, hal itu diserahkan kepada para pihak untuk menentukan pilihan hukum yang akan berlaku terhadap penyelesaian sengketanya.

Pelaksanaan putusan arbitrase dilakukan paling lama 30 hari sejak tanggal putusan diucapkan, kemudian lembar asli atau salinan otentik putusan arbitrase didaftarkan oleh arbiter atau kuasanya kepada panitera Pengadilan Negeri untuk mendapatkan kekuatan hukum dan kepastian hukum. Putusan arbitrase ini bersifat final dan mempunyai kekuatan hukum tetap dan mengikat para pihak untuk melakukan eksekusi. Jika pihak yang dikalahkan tidak mau melaksanakan putusan arbitrase dengan sukarela, Ketua Pengadilan Negeri yang melaksanakannya seperti suatu putusan pengadilan biasa yang sudah mempunyai kekuatan pasti. Hal ini sesuai dengan pasal $637 \mathrm{Rv}$. (Sugargo Gautama, 1999:129).

\section{d. Pelaksanaan Putusan Arbitrase}

Dalam melaksanakan putusan arbirase yang telah sedikit disinggung pada pembahasan putusan arbitrase, yang dalam pasal 59 ayat 1 menyatakan "Dalam jangka 30 (Tiga puluh) hari terhitung sejak tanggal putusan diucapkan, lembaran asli atau salinan otentik putusan arbitrase diserahkan dan didaftarkan oleh arbiter atau kuasanya kepada penitera pengadilan Negeri“. Dapat ditelaah dalam pasal 59 ayat 1 Undang- Undang Nomor 390 Tahun 1999 bahwa putusan Arbitrase selambat- lambatnya di daftar ke instasi yang menerima pendaftaran adalah Panitera Pengadilan Negeri. Adapun dalam pasal 60 menyatakan "Putusan Arbitrase bersifat final dan mempunyai kekuatan hukum tetap dan mengikat para pihak" artinya putusan arbitrase bersifat "final dan biding", hal ini berdasarkan kesepakatan para pihak. Dan perjanjian ini mengikat para pembuatnya sebagai undang-undang.maksud eksekusi putusan arbitrase seperti putusan pengadilan yang dapat dilihat dalam pasal 64 Undang-Undang Nomor 30 Tahun 1999 yang menyatakan "Putusan Arbitrase yang telah dibubuhi perintah Ketua Pengadilan Negeri, dilaksanakan sesuai ketentuan pelaksanaan putusan dalam perkara perdata yang putusannya telah mempunyai kekuatan hukum tetap". Jadi untuk meksankan lebih lanjut perintah dari Ketua Pengadilan Negeri ini, belaku lah peraturan-peraturan dalam HIR mengenai Eksekusi putusan- putusan dalam perkara Perdata 
yang sudah memperoleh status dapat dijalankan (kracht van gewjsde).

\section{Konsep Arbitrase Dalam Penyelesaian Sengketa Pertanahan}

Pelaksanaan arbitrase dalam sengketa perdata pertanahan sampai saat ini masih sebatas wacana dan konsep yang masih memerlukan penelitian terhadap kaidah hukum dan norma-norma yang mengatur terhadap penyelenggaraan sehingga apa yang akan disampaiakan dalam tulisan ini hanya sebatas kajian normatif.

Sebenamya menurut teori arbitrase bahwa sepanjang materi sengketa itu dikuasai sepenuhnya dan terbuka kesempatan untuk melakukan perdamaian maka hal itu dapat menjadi obyek penyelesaian secara arbitrase tanpa harus membeda-bedakan substansi sengketanya sepanjang masih dalam substansi perjanjian yang mengikat para pihak. Namun sebelum membahas lebih jauh mengenai sengketasengketa perdata tentang tanah maka penulis mencoba memberikan gambaran dan pemahaman tentang status tanah yang berada dalam pengusaha perdata.

Adapun status tanah menurut tinjauan administrasi pertanahan (administrasi pendaftaran tanah) secara umum oleh penulis dibagi menjadi dua kelompok yaitu kelompok tanah-tanah yang belum terdaftar (tanpa hak) dan kelompok tanah-tanah yang telah terdaftar (memiliki hak atas tanah) menurut UUPA. Tanah-tanah yang belum terdaftar menurut UUPA terdiri dan tanah-tanah negara yang dikuasai oleh perorangan dan tanah-tanah yang berasal dari bekas hak milik adat.

Dari kedua kelompok tanah tersebut jika terjadi permasalahan maka tinjauan khususnya tentunya berbeda pula, Hal ini terjadi karena bukti-bukti penguasaan tanahnya juga berbeda dengan demikian pula mekanisme dan administrasi perolehannya juga terdapat perbedaan bahkan instansi yang menangani datanya juga berbeda termasuk prediksi biaya penyelenggaraannya dan pengumpulan datanya.

Yang dimakasud tanah-tanah tanpa hak adalah tanah-tanah yang belum terdaftar menurut pasal 19 Undang-Undang nomor 5 tahun 1960 tentang peraturan Dasar pokok-pokok agraria dimana kantor perrtanahan artinya belum memiliki hak atas tanah sebagaimana di maksud dalam pasal 16 Undang-undang tersebut di atas.

Karena tanahnya belum terdaftar maka datanya belum tersimpan di kantor pertanahan sehingga informasi mengenai obyek sengketa sangat tergantung kepada kedua belah pihak yang bersengketa ditambah dengan kelengkapan data yang dimiliki oleh pemerintah setempat dimana obyek sengketa itu berada yang dimaksudkan ialah kantor lurah / desa dan kantor camat serta kantor notaris atau PPAT bahkan pada kantor pelayanan pajak bumi dan bangunan dimana obyek tersebut telah tercatat.

Tanah yang telah terdaftar menurut pasal 19 Undang-undang Nomor 5 Tahun 1960 tentang Peraturan Dasar Pokok-pokok Agraria adalah tanah yang telah tercatat secara administrasi di Kantor Pertanahan sehingga telah 
memiliki salah satu hak sebagaimana dimaksud dalam pasal 16 undangundang tersebut di atas.

Adapun beberapa hal yang perlu di perhatikan bila mana terjadi sengketa perdata atas tanah yaitu :

1. Subyek yang bersengketa;

2. Obyek yang di sengketakan;

3. Surat-surat bukti penguasaan obyek sengketa;

4. Substansi sengketanya.

Subyek sengketa yang dimaksud adalah pihak yang menguasai obyek sengketa sepenuhnya dan pihak-pihak yang berkepentingan langsung dengan obyek di sengketakan sedangkan obyek disengketakan itu haruslah nyata spesifik, dan jelas secara fisik termasuk batas-batasnya. Surat tanda bukti dan obyek sengketa harus jelas hubungannya antara obyek dan subyeknya sedangkan substansi atau materi dari sengketa itu haruslah berupa sengketa yang dapat dilakukan upaya perdamaian.

\section{Konsep Perjanjian Pactum De Compromittendo}

Terhadap obyek sengketa perdata yang dalam perjanjian pokoknya telah dilekati perjanjian asseson berupa pactum de compromittendo maka pihak pengadilan negeri setempat tidak berwenang untuk menangani sengketanya tetapi hakim akan menyerahkan penyelesaian sengketanya kepada arbiter mana yang telah ditunjuk dalam klausulanya sesuai Pasal 11 ayat (1) dan (2) Undang-Undang Nomor 30 Tahun 1999 tentang Arbitrase dan altematif penyelesaian sengketa.

Peluang dimuatnya klausula arbitrase dalam perjanjian perdata pertanahan dapat dilekatkan secara langsung pada perjanjian pokoknya yaitu pada pasal-pasal yang masih kosong dalam lembaran akte peralihan hak atas tanah yang telah ada.

Dalam format akte peralihan hak misalnya akte jual bell, akte hibah, akte tukar menukar, akte hibah wasiat dan sebagainya masih terdapat pasal-pasal yang sengaja dikosongkan untuk memberi kesempatan kepada para pihak yang membuat perjanjign diatas akte tersebut untuk mencamtungkan hal-hal yang bersifat mengikat kedua belah pihak misalnya tentang klausula arbitrase jika hal itu dikehendaki.

Adapun contoh dan perjanjian tambahan misalnya pada akte jual beli dalam pasal 6 dapat di tuliskan kalimat yang berbunyi sebagai berikut : 'Bila mana kemudian hal terjadi sengketa maka kami para pihan akan menyerahkan penyelesaiannya pada lembaga arbitrase A yang ada di makassar atau "bila mana kemudian hari terjadi sengketa maka kami dan pihak akan menunjuk arbiter untuk menyelesaikan sengketa tersebut.' Dan masih banyak lagi kalimat atau klausula arbitrase yang dapat di buat sebagai suatu kesepakatan untuk mengikatkan diri. 
Bilamana perjanjian arbitrase itu telah di buat dan disepakati kemudian terjadi sengketa perdata maka pihak yang merasa dirugikan dapat menyurat (melakukan penyampaian tertulis) kepada pihak lainnya untuk melakukan gugatan arbitrase sehinggah tidak perlu melalui mekanisme yang panjang sampai sengketanya dapat ditangani dan diselesaikan secara final dan mengikat.

Berikutnya ditetapkanlah acara arbitrase sebagaiman yang telah ditetapkan oleh Undang-Undang Nomor 30 Tahun 1999, adapun bentuk acaranya tidak harus sama persis yang diuraikan dalam undang-undang tersebut tetapi dapat dimodifikasi sesuai dengan kebutuhan para pihak sepanjang hal itu tidak bertentangan dengan hukum,keadilan dan kepatuhan.

Bilamana dalam pemeriksaan sengketanya dibutuhkan keterlibatan pihak lain untuk dijadikan sebagai bahan pertimbangan untuk meyakinkan para arbiter maka hal itu dapat saja dilakukan sepanjang kedua pihak yang bersengketa menghendakinya.

Dalam pemeriksaan sengketa ini terdapat hal yang sangat perlu diperhatikan selain keterangan para pihak dan saksi maupun saksi ahli yaitu kepastian obyek yang disengketakan dan kebenaran serta akurasi data atau surat-surat tanda bukti yang diajukan oleh para pihak.

Setelah data dan keterangan dianggap lengkap maka tahapan berikutnya yang harus dilakukan adalah analisis data dan pertimbangan, hal itu harus dilakukan mengingat perlunya singkronasi antara data dan keterangan-keterangan dari pihak yang dianggap relevan dengan masalahnya.

Tahapan selanjutnya dilakukan suatu keputusan yang bersifat final dan mengikat kedua belah pihak, oleh karna itu sebelum keputusan itu di tanda tangani oleh para pihak dan arbiternya maka terlebih dahulu dapat dikoreksi atau direvisi jika hal itu dikehendaki.

Dalam jangka waktu paling lama lama 30 hari terhitung sejak tanggal putusan diucapkan maka lembaran asli atau salinan outentik putusan arbitrase diserahkan dan didaftarkan kepada panitera pengadilan negeri. Karena keputusan arbitrase ini sifatnya final dan mengikat maka para pihak harus melaksanakan putusan arbitrase ini dan bilamana ada salah satu pihak tidak bersedia melaksanakan putusan arbitrase secara sukarela maka putusan di laksanakan berdasarkan perintah ketua pengadilan negeri atas permohonan salah satu pihak yang bersengketa.

\section{Konsep Akta Kompromis}

Sebagaimana telah dijelaskan dalam bab sebelumnya bahwa akta kompromis dibuat oleh para pihaksetelah terjadinya sengketa sehingga hal itu lebih memudahkan kedua belah pihak setelah untuk menunjuk arbiter yang mereka kehendaki baik itu lembaga arbitase maupun arbitase ad-hoc ataupun arbiter tunggal sedangkan acaranya sama saja yaitu sifatnya tidak 
kaku sesuai dengan kebutuhan para pihak.

Dalam hal penetapan prosedur dan mekanisme beracara maka peranan arbiter yang telah ditunjuk adalah sangat besar dalam memberikan pilihan acara yang dikehendaki oleh para pihak yang dianggap lebih efisien, efektif den menguntungkan keduanya sepanjang tidak mengurangi standar bersama.

Bentuk atau format perjanjiannya tidak ditetapkan namun demikian, substansinya tidak boleh bertentangan. Dengan ketentuan dalam Undangundang Nomor 30 Tahun 1999 khususnya Pasal 9 Ayat 1 dan 2 dan ketentuan dalam kitab Undang-Undang Hukum Perdata tentang perjanjian serta tidak boleh melanggar kesusilaan dan ketertiban umum (Pasal 137 KHUP).

\section{Kendala Penerapan Arbitase Dalam Sengketa Pertahanan}

Latar belakang lahirnya ketentuan normatif mengena arbitrase ini adalah untuk menyelesaikan sengketa bidang bisnis, keuangan dan perbankan sehingga dalam prakteknya ketentuan ini hanya dimanfaatkan oleh mereka yang terlibat dalam bidang-bidang tersebut diatas padahal ketentuan ini tidak membatasi pemberlakuannya sepanjang memenuhi yang ditetapkan dalam Pasal 5 Undang-Undang Nomor 30 Tahun 1999 tentang Arbitrase dan Altematif Penyelesaian Sengketa.

Jika ketentuan ini diterapkan dalam sengketa perdata pertanahan maka hal itu akan menghadapi beberapa kendala baik kendala teknis dan administrasi, yuridis, maupun sosial kulturalnya.

Kendala teknis dan administrasi yang dihadapi antara lain masih ada aparat penegak hukum yang belum mengerti mengenai arbitrase, belum ada lembaga arbitrase pertanahan, lembaga arbitrase belum mempersiapkan arbiternya untuk menangani sengketa peranahan.

Kendala yuridisnya yaitu substansi hukum dalam undangundang arbitrase yang mangatur hal sengketa pertanahan tidak jelas sedangkan ketentuan dalam Pasal 5 dan Pasal 11 Undang Undang Nomor 30 Tahun 1999 tentang Arbitrase dan Altematif Penyelesaian Sengketa belum dapat menjamin penyelenggaraan arbitrase pertanahan secara kongkrit.

Kendala sosio-kultural dalam masyarakat yaitu selama ini masysarakat terlanjur terbiasa menghadapi permasalahannya melalui peradilan formal, ada kesan bahwa bararbitrase akan mengambil alih kewenangan aparan penegak hukum, kurangnya sosialisasi tentang arbitrase kepada masyarakat.

\section{KESIMPULAN}

Peradilan arbitrase dapat diterapkan terhadap obyek sengketa perdata pertanahan, baik tanah-tanah yang telah memiliki hak atas tanah maupun atas tanah-tanah yang belum mempunyai hak. Di masa yang akan datang besar 
kemungkinananya dapat diterapkan klausula arbitrase pada perjanjian pokok dengan mencantumkan dalam pasal-pasal akte peralihan haknya.

Mekanisme dan prosedur lembaga arbitrase pertanahan sangat sederhana seperti halnya peradilan arbitrase pada sengketa perdangangan dan perbankan hanya saja perlu ditambahkan fase analisis data dan pertimbangan untuk menemukan suatu sinkronisasi antara data dan keterangan, antara data yuridis dan data fisik, guna mendapatkan suatu keputusan yang adil dan benar. Prosedur beracaranya tetap seperti dalam ketentuan undang-undang arbitrase kecuali bila diperlukan untuk menyakinkan majelis arbitrase, maka dapat dilakukan peninjauan setempat.

\section{DAFTAR PUSTAKA}

A. Rahmat Rosyadi dan Ngatino, 2002, Arbitrase Dalam Perspektif Islam Dan Hukum Positif, PT. Citra Aditya Bakti, Bandung.

Acmad Ali, 2002(a), Menguak Tabir Hukum (Suatu Kajian Filosofis dan Sosiologis), PT. Toko Gunung Agung Tbk, Jakarta.

----------, 2002(b), Keterpurukan Hukum di Indonesia (Penyebab dan Solusinya ), Ghalia Indonesia, Jakarta.

----------, 2003, Mengapa Memilih Mediasi (Makalah Dalam Rangka Seminar dan Diklat Peningkatan SDM Badan Pertanahan Nasional di Hotel Marannu Makassar).

Boedi. Harsono, 2004. Hukum Agraria Indonesia Himpunan Peraturan Hukum Tanah Indonesia. Jakarta : Djambatan.

Hambali Thalib dan Syamsuddin Pasamai, 2009, Sejarah Hukum (Dalam Dinamika IImu Hukum), Umitoha Ukhuwah Grafika, Makassar.

Priyatna Abdurrasyid, dkk., 2001, Prospek dan Pelaksanaan Arbitrase di Indonesia, PT. Citra Aditya Bakhti, Bandung.

Saifuddin Azwar, 2001, Metode Penelitian (cetakan ke 20, Pustaka Pelajar), Yogyakarta

Soerjono Soekanto dan Sri Mamuji, 2001, Penelitian Hukum Normatif Suatu Tinjauan Singkat (cetaka ke 5), PT. Raja Grafindo Persada, Jakarta.

Sudargo Gautama, 1999, Undang-Undang Arbitrase Baru 1999, PT. Citra Aditya Bakti, Bandung. 